\title{
ARQUITETURA E MOBILIÁRIO COMO HISTÓRIA NA BIBLIOTECA JOANINA DE COIMBRA, PORTUGAL*
}

\author{
Janaina Cardoso de Mello**
}

RESUMO: Com suntuosa arquitetura e mobiliário que refletia o poder e o saber na história portuguesa, a Biblioteca Joanina, no setecentos tonou-se um ambiente importante para o ofício de arquitetos, mestre-de-obras, entalhadores, pintores e douradores. O objetivo desse estudo é compreender a relação entre arquitetura, mobiliário e história na biblioteca, investigando forma e contexto da representação do poder régio ilustrado, descortinando assim linguagens aproximativas e destoantes em suas singularidades.

PALAVRAS-CHAVE: Biblioteca Joanina; Arquitetura; Mobiliário; Poder.

\section{Architecture and furniture as history in the Joanina Library of Coimbra, Portugal}

ABSTRACT: Artistic and architectural works that reflected the power and knowledge in Portuguese history, the Biblioteca Joanina, in 700th siècle became an environment important to the Office to architects, foreman, carvers, painters and gilders. The aim of this study is to understand the relationship between architecture, furniture and history in the library, researching form and context of the representation of the Regal power illustrated, unveiling how approximate languages and mixed in their singularities.

KEYWORDS: Joanina Library; Architecture; Furniture; Power.

\section{Arquitectura y mobiliario como historia en la Biblioteca Joanina de Coimbra, Portugal}

RESUMEN: Trabajo arquitectónico y artístico que refleja el poder y conocimiento en la historia portuguesa, la Biblioteca Joanina, en 700 se convirtió en un ambiente importante para la oficina de arquitectos, capataz, escultores, pintores y doradores. El objetivo de este estudio es entender la relación arquitectura, mobiliario e historia en la biblioteca, investigando la forma y el contexto de la representación del poder Regio ilustrado, revelando así los lenguajes aproximados y mixtos en sus singularidades.

PALABRAS CLAVE: Biblioteca Joanina; Arquitectura; Mobiliario; Poder.

\footnotetext{
*Texto dedicado à Profa. Dra. Tania Bessone (UERJ) em agradecimento ao aprendizado sobre a história das bibliotecas.

**Pós-Doutoranda em Estudos Culturais pela Universidade Federal do Rio de Janeiro, Doutora em História Social pela Universidade Federal do Rio de Janeiro. Atualmente, Professora Adjunta do Departamento de História da Universidade Federal de Sergipe, do Mestrado Profissional em Ensino de História (ProfHistóriaUFS) e do Mestrado em História da Universidade Federal de Alagoas. Contato: Cidade Universitária Prof. José Aloísio de Campos, Av. Marechal Rondon, s/n, Jd. Rosa Elze, CEP 49100-000, São Cristóvão/SE, Brasil. Email: janainamello.ufs@gmail.com
} 


\section{Introdução}

"La bibliothèque la plus fastueuse que j'ai jamais vue".

(Germain Bazin)

A Biblioteca Joanina em sua arquitetura e mobiliário, que remonta a história setecentista portuguesa, são os objetos de pesquisa e análise nesse artigo. Incorporada à Biblioteca Geral da Universidade de Coimbra, a Biblioteca Joanina, candidata ao título de patrimônio universal da humanidade sob a chancela da UNESCO, contém um fundo composto por livros antigos que compreende desde o período medieval até 1830 , perfazendo mais de cem mil volumes. ${ }^{1}$

A data de sua criação é desconhecida, havendo indicação de que antes mesmo da transferência da Universidade para Coimbra, em 1537, já existia uma "Livraria de Estudo". Entretanto até 1705 essa "Livraria" foi abrigada em vários espaços até sua reabertura no edifício hoje conhecido como Biblioteca Joanina. ${ }^{2}$

Foi a instituição de Coimbra um cerne de discórdias e competições reais quando em 1796 seu bibliotecário, António Ribeiro dos Santos, foi convocado por D. Maria I para assumir o posto de Bibliotecário-Mor da Biblioteca Real da Corte em Lisboa. A rainha visava levar para o âmbito régio preciosos conhecimentos da organização do mundo letrado, mas também descentralizar o saber/poder outrora personificado sob a égide da Universidade de Coimbra e suas bibliotecas. ${ }^{3}$

O ponto de partida para a análise da arquitetura, mobiliário e história contidas na instituição em foco advém primeiro do interesse despertado pela visita técnica realizada na mesma, em novembro de 2009, inferindo, portanto, uma metodologia de observação participativa para reconhecimento do espaço e coleta de dados. Posteriormente ao levantamento de bibliografia pertinente, buscou-se cotejá-la com a coleção de Cartões Postais da Biblioteca Joanina, com 12 lâminas coloridas $(10,5 \times 15 \mathrm{~cm}) .{ }^{4}$ Por fim, foi utilizada a mídia digital "Biblioteca Joanina" (Biblioteca Joanina Virtual - João V's Baroque virtual library) ${ }^{5}$ configurada no DVD-ROM, produzido em 2008, para a percepção dos múltiplos e distintos suportes de salvaguarda de seu corpus documental.

Segue-se a noção de "documento ampliado", proposta por Jacques Le Goff, entendendo-o não somente como aquele produzido de modo escrito, mas também ilustrado, sonoro, imagético, dentre outros. ${ }^{6}$ 
Vale ressaltar que data do reinado de D. João V, no setecentos, o surgimento do barroco português manifesto na arquitetura, no azulejo, na talha, no mobiliário e na ourivesaria. $^{7}$ Nesse sentido, todos os recursos arquitetônicos e estéticos no compasso da ideologia artística que norteava aquela sociedade foram colocados em curso para o soerguimento da grandiosidade não somente da biblioteca, mas também do rei que a personificava.

O objetivo que norteia esse estudo é compreender a relação entre arquitetura, mobiliário e história na biblioteca, investigando forma e contexto da representação do poder régio ilustrado, descortinando assim linguagens aproximativas e destoantes em suas singularidades.

Trata-se neste trabalho dos detalhes arquitetônicos externos e internos da biblioteca, o mobiliário (estantes e mesas com seus entalhes decorativos), bem como as pinturas (tetos das salas e retrato de D. João V). Mas também são nomeados seus artífices, uma vez que a obra é uma construção coletiva de muitos talentos artísticos.

\section{Entre colunas, brasões e armas: a arquitetura barroca joanina do saber como poder (1717-1725)}

Localizada estrategicamente no centro de Portugal, entre duas áreas metropolitanas importantes (Porto e Lisboa), Coimbra possui aproximadamente $319,41 \mathrm{~km}^{2}$ de área territorial, possuindo uma demografia com mais de 143 mil habitantes (censo de 2011). É banhada pelo rio Mondego ${ }^{8}$ e sua história tem início:

[...] no período romano, sendo a herdeira de duas realidades territoriais diversas, a de Aeminium, situada onde se eleva hoje a Alta - que na preimeira metade do século II a.C. começa a adquirir um papel preponderante na organização do território - e a da mais conhecida e distante Conimbriga, da qual recolherá o nome e as funções principais. ${ }^{9}$

A primeira universidade portuguesa, fundada por D. Dinis em 1290, dedicada aos Estudos Gerais, manteve um caráter de itinerância entre Lisboa e Coimbra, ocupando a partir de 1308, em Coimbra, um edifício próprio e mais tarde, entre 1354 e 1377, estabelecendo-se na baixa da cidade. Porém data de 1537 a manutenção definitiva da universidade em Coimbra, transformando-se o Paço Real na principal morada universitária. ${ }^{10}$

Durante o reinado de D. João V (1707-1750) são construídas a Biblioteca Joanina considerada uma das mais belas bibliotecas universitárias do mundo, e a Torre da Universidade - que alberga o relógio e os sinos que regulam o tempo estudantil e 
estava pensada como observatório astronómico. Ambos são fruto da vontade em promover a atualização cultural e científica e do acolhimento de ideias iluministas. ${ }^{11}$

Mas a história de sua construção merece um maior detalhamento. $\mathrm{O}$ pedido de obras para a organização da biblioteca já existente em uma sala, feito por Nuno da Silva Teles (prelado da época), foi atendido por D. João $\mathrm{V}$ de forma mais expansiva uma vez que o rei determinou em 1716 que fosse construido um edifício em local adequado. ${ }^{12}$

O espaço escolhido era contíguo às dependências da instituição universitária e ao lado direito de sua Capela, sendo a obra iniciada em 1717, estando toda a parte de pedraria já concluída em 1722 e restando somente a parte interna de carpintaria. Em 1728, a Biblioteca Joanina estava pronta. ${ }^{13}$

Devido ao desnível do terreno, a obra foi concebida como um paralelepípedo com três pisos. No piso inferior ficaram restos do antigo cárcere real e o intermediário foi destinado ao uso dos professores. No terceiro piso, o andar nobre, é que se concentram as dependências da biblioteca, que proporciona condições excepcionais para a conservação dos seus documentos como a temperatura constante, entre 18 a 20 graus Celsius e humidade relativa do ar estável, de cerca de $60 \%$. Na fachada de acesso, voltada ao Pátio, fica o portal nobre, que segundo consta, surgia com a monumentalidade de um arco de triunfo, mas que lastimavelmente se quebrou. ${ }^{14}$

A coleção de cartões postais da Biblioteca Joanina da Universidade de Coimbra dedica três lâminas à arquitetura, ocupação espacial e detalhe estético externo do edifício. Uma das lâminas apresenta o pátio da universidade do lado poente, onde se pode visualizar a torre do relógio, a universidade e a biblioteca (figura 1). A segunda lâmina traz o exterior com uma apoximação maior da Biblioteca Joanina em seu retângulo arquitetônico. A terceira lâmina é uma fotografia ampliada do brasão da porta principal.

Figura 1 - Universidade de Coimbra, Biblioteca Joanina (séc. XVIII), Pátio da Universidade, lado poente.

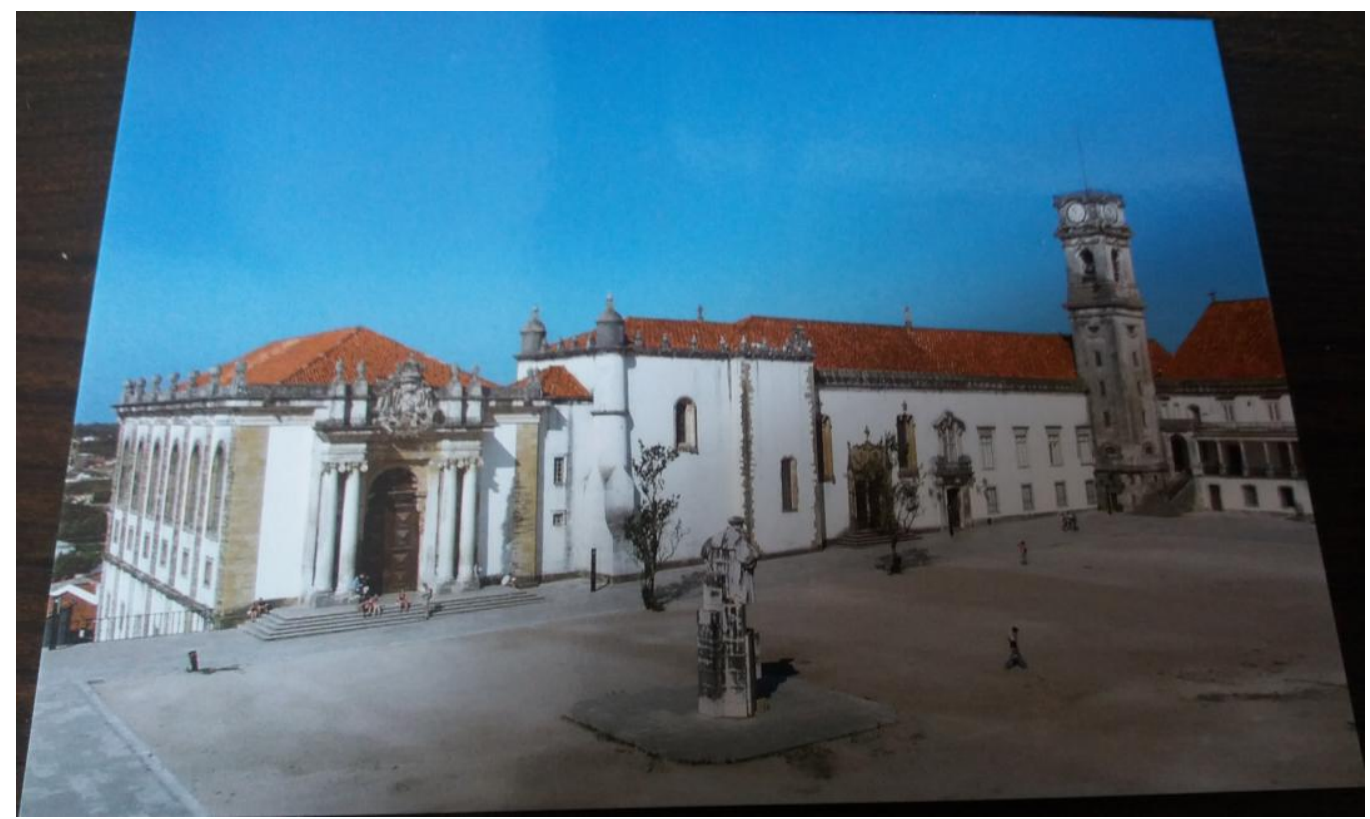

Fonte: Biblioteca Geral da Universidade de Coimbra. Biblioteca Joanina. Coleção de Postais (fotografia, design, execução: SerSilito), Coimbra, BGUC, s/d. (12 lâminas). 
Monumento da arquitetura civil, seu mestre de obras foi João Carvalho Ferreira, substituído mais tarde por Gaspar Ferreira em função das dúvidas que se tinha sobre o potencial do primeiro em interpretar a planta baixa da obra de acentuada verticalidade. ${ }^{15}$

Consta que Gaspar Ferreira foi auxiliado por Manuel Moreira na função de arquiteto, tendo como pedreiro António Martins João e André Salgado no ofício de vidraceiro. A fachada da Biblioteca Joanina foi um trabalho atribuído a Claude de Laprade, desse modo, "a entrada, coroada pelas armas do reino, recorda que esta é uma obra executada sob real patrocínio". Valoriza também o uso do material em pedra calcária (de Ançã-Portunhos) no portal com quatro culunas. Trazendo ainda a inscrição: "Esta é a sede que Coimbra Augusta deu aos livros, para que a Biblioteca lhe coroe a testa". ${ }^{16}$

Sob os pés, a parte terrena que evoca a complexidade de desenhos geométricos cheios de sentidos que coligam a realeza ao saber letrado, assim,

[...] o piso nobre seria, essencialmente, o produto da repartição de um retângulo em três retângulos menores, intercomunicantes através de uma sequência de arcos que reproduzem, no seu esquema geral, o portal de acesso, desprovido das colunas, mas sobrepujado, de forma idêntica, de uma cartela heráldica coroada, albergando agora as insígnias das faculdades universitárias. ${ }^{17}$

Na obra "História Breve de Coimbra" publicada em 1733, em Lisboa, Bernardo de Brito Botelho ao descrever a Universidade de Coimbra relata:

\footnotetext{
Juncto a esta real capella, se faz de proximo uma grandiosa livraria, com grandioso portico, e magnifico edificio, que em quanto ao material, por fora e por dentro, está acabada; falta o ornato dos livros, que na direcção, ordem, e custo, será uma das maravilhas de Europa; pois só no material da obra, pinturas, e dourados, que ainda vão continuando, se tem gasto, até o anno de 1725 , cento e cincoenta e oito mil e tantos cruzados. O custo dos livros de todas as artes e sciencias chegarão a somma extraordinária. ${ }^{18}$
}

O valor total despendido com a parte arquitetônica, o conforto interior e estético da Biblioteca, assim como a aquisição do acervo seria orçado, após 1728, em "sessenta e seis contos seiscentos e vinte e dois mil, cento e vinte e nove réis, fora quatorze contos trezentos e oitenta e cinco mil réis empregados na compra de livros". ${ }^{19}$

O rico acervo guarda uma $1 .^{a}$ edição de Os Lusíadas, a coleção de manuscritos e documentos de Almeida Garrett, Dicionários Tupi-Português, os originais dos desenhos de arquitetura da Reforma Pombalina, um texto inédito e ilustrado do bispo português de Malaca D. João Ribeiro Gaio, a Bíblia Hebraica de Abravanel (da qual há apenas 20 exemplares no 
mundo), a Bíblia das 48 linhas que foi dada à estampa pelos sócios de Gutenberg, o primeiro de três volumes manuscritos do Antigo Testamento. uma Bíblia românica do século XII, Bíblias góticas dos séculos XIII e XIV ou ainda o primeiro estudo de conjunto das Bíblias manuscritas iluminadas. Também estão acondicionados no local vários códices e iluminuras, passando pelas edições quinhentistas, revistas científicas e livros mais recentes.

O "rei Sol" português pretendia eternizar-se criando uma "cultura política" onde a arte e o saber letrado referendavam sua coroa e seu cetro na perspectiva daquele que irradia conhecimento e beleza, na estética do exagero, abrigando em barrocas estantes os livros formativos da nação.

Ao pesquisar a produção da leitura (enquanto técnica), bem como a relação social entre homens e livros, a historiadora Tania Bessone vê na formação das bibliotecas "[...] referências importantes para conhecer suas ambições como indivíduos e como homens públicos". 20

Para Katherine Both a Biblioteca Joanina torna-se um símbolo pois “[...] não só indica o papel mecenato do monarca D. João V, mas também a 'realeza' do homem que estuda, tornando-se um defensor do conhecimento e da sabedoria". ${ }^{21}$

Sob os auspícios do ouro vindo do Brasil e a série de construções impulsionadas no reinado de $\mathrm{D}$. João $\mathrm{V}$, inúmeros artistas vieram de outros países para exercer seu ofício no Palácio-Convento de Mafra, nos monumentos do Porto (Igreja e Torre dos Clérigos, Misericórdia, Paço Episcopal, Palácio do Freixo), nos solares da região do Minho, dentre outros espaços lusitanos. Destacaram-se os desenhos arquitetônicos do alemão Ludovice, os italianos Giasti, Trevisani, Biancti, além de Nicolau Nasoni. ${ }^{22}$

\section{Mobiliário exótico com entalhes dourados: a arte de Francesco Gualdini (ou Francesco Realdino) e Manuel da Silva}

O mobiliário barroco presente na Biblioteca Joanina da Universidade de Coimbra traduz a concepção ornamentada do "gosto pelo movimento de massas desproporcionadas e de formas irregulares, a oposição entre a luz e a sombra, a busca da ênfase e a criação de efeitos de surpresa". ${ }^{23}$

Mesas retangulares, suntuosas, com tampo marchetado apresentando um mosaico de folheados com figuras geométricas (em madeira de talha), pés no formato de balaústres ricamente entalhados em madeira com motivos dourados e incrustrados (figura 2) são rodeadas por estantes cuidadosamente ornamentadas repletas de valiosos livros antigos como 
expõe as quatro lâminas dos postais da coleção Biblioteca Joanina (vista geral do interior, as estantes, mesas e estantes e a decoração das estantes).

Figura 2 - Universidade de Coimbra, Biblioteca Joanina (séc. XVIII), Mesas e estantes

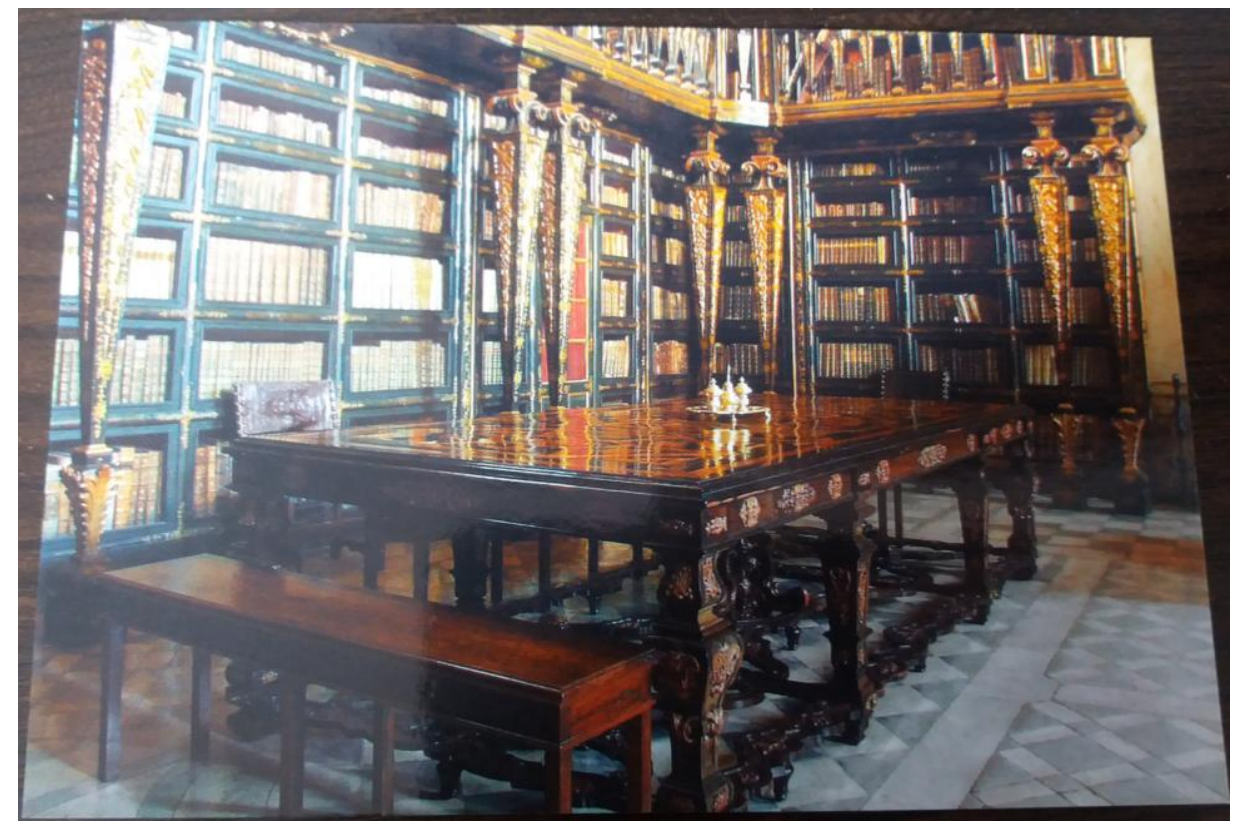

Fonte: Biblioteca Geral da Universidade de Coimbra. Biblioteca Joanina. Coleção de Postais (fotografia, design, execução: SerSilito), Coimbra, BGUC, s/d. (12 lâminas).

As grandes mesas de leitura que compõem parte do mobiliário da Biblioteca Joanina datam de 1724, tendo sua concepção e execução sido obra do entalhador Francesco Gualdini. O par de mesas idealizado para cada sala foi feito com madeira exótica de várias cores oriundas do Brasil e do Oriente. ${ }^{24}$

Já as varandas, estantes e chinoiseries, também de 1724, tiveram a concepção e execução de Francesco Gualdini e João Rodrigues de Almeida, sendo Gaspar Ferreira o mestre-de-obras e Manuel da Silva o responsável pela pintura dourada. ${ }^{25}$

As cores (em laca verde, vermelha e negra) variam nas estantes de cada sala, criando um ambiente diferente em cada uma delas. Todas têm dois andares, com um varandim e escadas de acesso aos livros embebidas engenhosamente nas estantes. ${ }^{26}$

O verniz em laca, técnica nomeada de "charão", foi desenvolvido pelos chineses (entre 1600 e 1046 a.C., na dinastia Shang). A laca era um verniz natural extraído da seiva da árvore-da-laca, aplicado especialmente em mobiliários e peças decorativas. Da mistura da laca com o cinábrio os chineses produziram o charão vermelho. ${ }^{27}$

No que diz respeito as estantes lacadas em verde, vermelho e negro, as mesmas possuem decorações de motivos chineses em dourado (figura 3) que foram executadas por 
Manuel da Silva, no período de 1723 a 1727, um mestre pintor, residente em Coimbra. O valor a ser pago por seu trabalho foi orçado em três mil cruzados e oitenta mil réis, com contrato tendo por testemunha o vice-reitor da universidade Manuel Borges Cerqueira. ${ }^{28}$

Figura 3 - Universidade de Coimbra, Biblioteca Joanina (séc. XVIII), Decoração das estantes

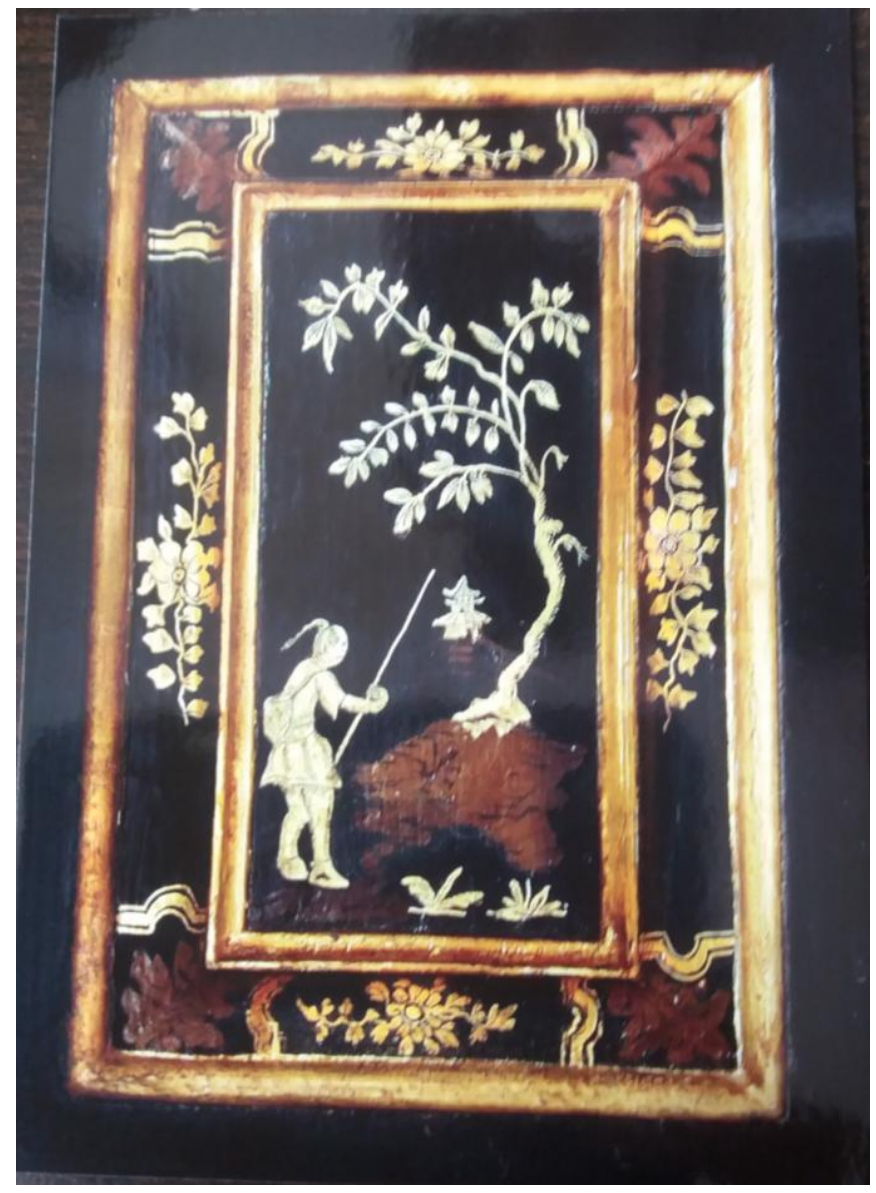

Fonte: Biblioteca Geral da Universidade de Coimbra. Biblioteca Joanina. Coleção de Postais (fotografia, design, execução: SerSilito), Coimbra, BGUC, s/d. (12 lâminas).

Há uma confusão quanto ao nome do entalhador das mesas e estantes. Carlos Fiolhais e A. E. Maia do Amaral em seus livros o chamam de "Francesco Realdino"29, entretanto, o realtório técnico da Biblioteca Joanina (elaborado por A. E. Maia do Amaral) e a coleção de Cartões Postais da mesma instituição lhe atribui o nome de "Francesco Gualdini", 30

De qualquer modo, se diz do entalhador Francesco [?] que era italiano, morador de Lisboa e fora contratado em 1725 para a realização de seis suntuosos bufetes ou mesas de leituras, concluindo seu serviço dois anos depois. ${ }^{31}$ Teria utilizado madeiras tropicais (ébano, gandarú ou petiá). E nos seus tampos, reluziam sob uma bandeja acessórios de escrita como o tinteiro e a pena, além da sineta, todos dourados. ${ }^{32}$ 
António José de Oliveira ao pesquisar os entalhadores, douradores e pintores portugueses entre 1572 e 1798, apresenta uma relação de nomes onde consta o de "Manuel da Silva" - mestre ensamblador, morador de Ponte de Serves, da Freguesia de S. Teodoro de Pedome [atual conselho de Vila Nova de Famalicão] -, contratado em 1723 pela Reverenda Madre Benta de Jesus, prioresa do convento, para obra do cadeiral e assentos do coro alto da igreja do Carmo. ${ }^{33}$ Acredita-se que seja o mesmo Manoel entalhador da Biblioteca Joanina, uma vez que no período havia uma intensa mobilidade de artífices nas regiões portuguesas e ainda para a América Portuguesa.

Ressalta-se que as varandas da Biblioteca Joanina têm como suporte colunas piramidais invertidas, com capitéis ornamentados com duas volutas e decoração em motivos de chinoiseries com aplicações em ouro, elaboradas por Manuel da Silva no período de quarenta meses. $^{34}$

Imbuídos da inspiração que esse espaço propiciava estiveram escritores oitocentistas como Almeida Garret, Eça de Queiroz e Antero de Quental, quando ainda eram alunos da Universidade de Coimbra, sentados nos bancos corridos de pau santo. ${ }^{35}$

Entretanto, de acordo com os estudos de Terezinha Elizabeth da Silva "na Biblioteca Joanina, o ouro, o desenho das estantes, as colunas em ponta e os arabescos confundem os olhos e enganam os sentidos. Os ornamentos nada discretos provocam vertigens". Para a autora, as formas estéticas transcendem e extrapolam a função de abrigo de livros e da leitura de uma biblioteca, enaltecendo muito mais os criadores do espaço do que o propósito ali contido: o saber. São marcos do desejo de imortalidade, da força divina do saber e da realeza ali corporificada. ${ }^{36}$

\section{No limiar das reformas do Marquês de Pombal: afrescos dos tetos e cimalhas de António Simões Ribeiro e Vicente Nunes}

E o olhar para o alto poderia distrair qualquer um de sua utilidade prática: a leitura, entretanto, faria qualquer leitor viajar em seu imaginário como na posse de um livro. Desse modo, os tetos das três salas da Biblioteca Joanina eram obras de arte de tirar o fôlego com pinturas sem perspectiva de autoria de António Simões Ribeiro e Vicente Nunes.

Três lâminas da coleção de postais da Biblioteca Joanina são dedicadas às pinturas dos tetos das três salas. Houve uma preocupação em demonstrar a centralidade das imagens representativas do saber, em sua composição entre anjos, nuvens e pilastras adornadas. 
Figura 4 - Universidade de Coimbra, Biblioteca Joanina (séc. XVIII), Teto da primeira sala.

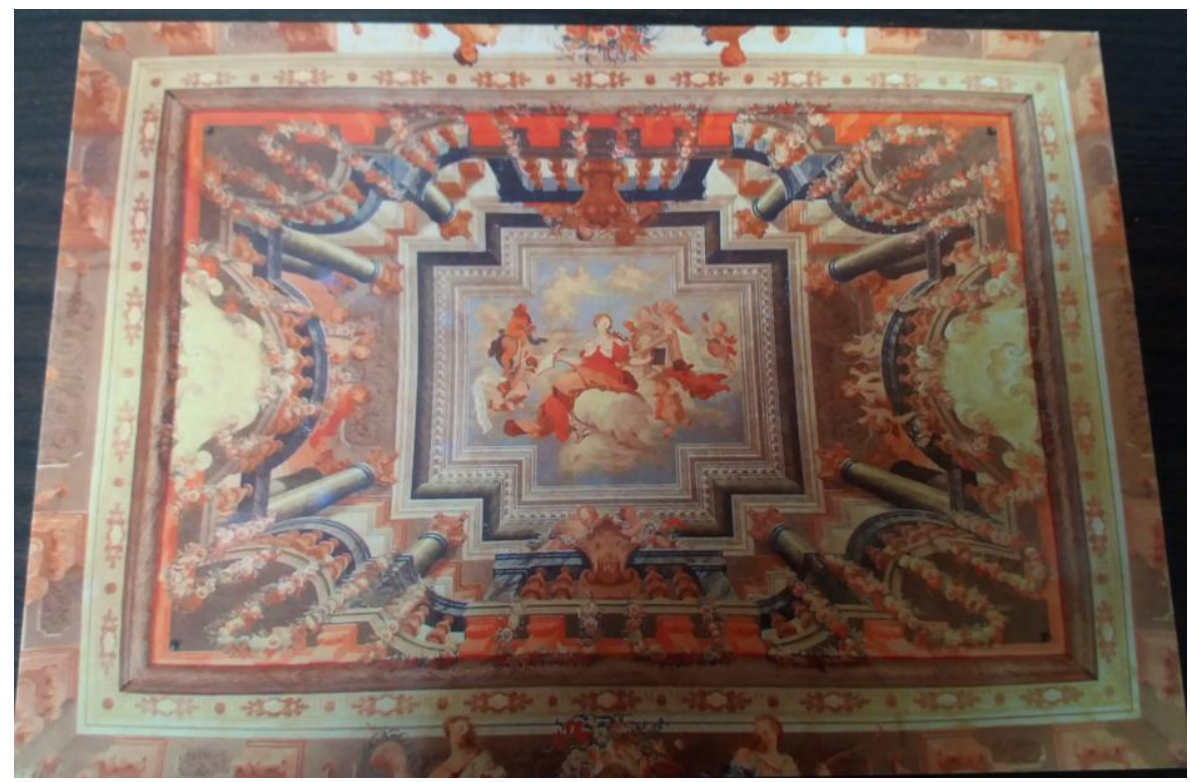

Fonte: Biblioteca Geral da Universidade de Coimbra. Biblioteca Joanina. Coleção de Postais (fotografia, design, execução: SerSilito), Coimbra, BGUC, s/d. (12 lâminas).

Na primeira sala, a alegoria da Sabedoria (universidade) ocupa o lugar central no teto, repousando em nuvens macias e rodeada de figuras aladas (anjos) que lhe entregam livros. A sanca (cimalha) ao redor apresenta quatro imagens femininas cuja representação evoca os quatro continentes: Europa, América, África e Ásia (figura 4).

Figura 5 - Universidade de Coimbra, Biblioteca Joanina (séc. XVIII), Teto da segunda sala

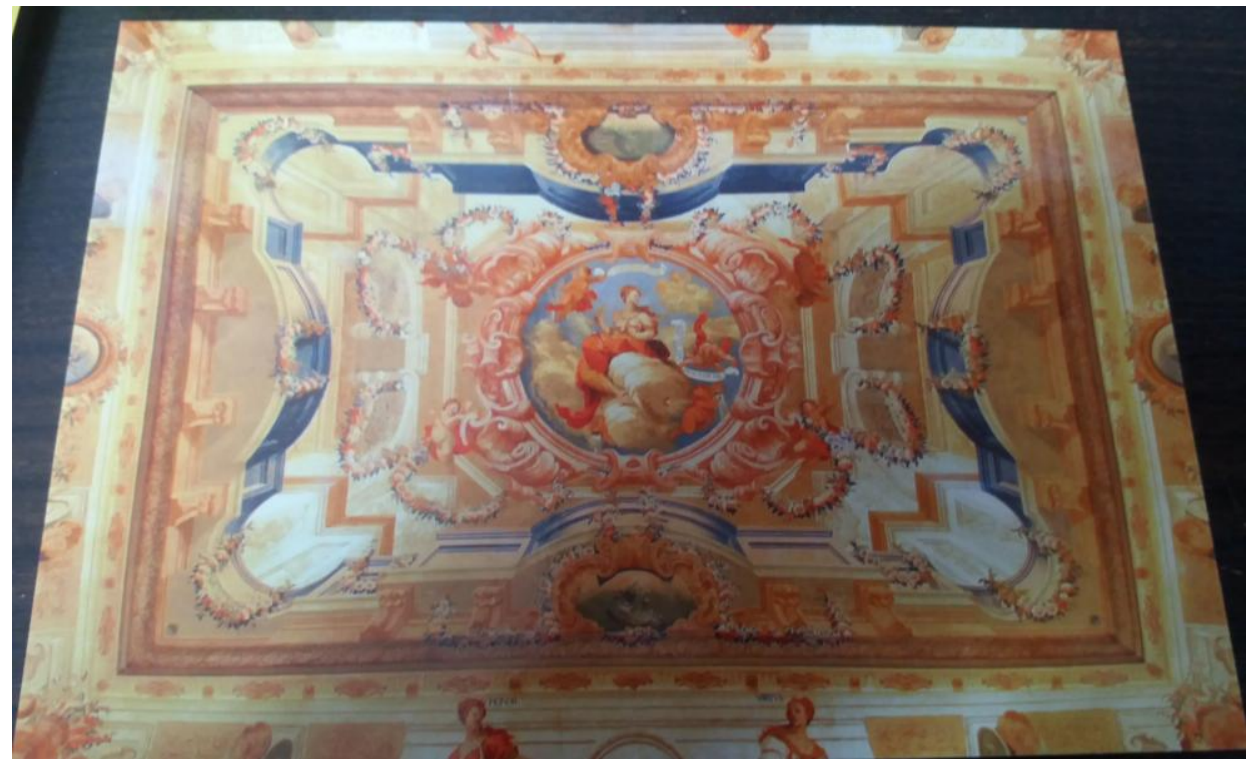

Fonte: Biblioteca Geral da Universidade de Coimbra. Biblioteca Joanina. Coleção de Postais (fotografia, design, execução: SerSilito), Coimbra, BGUC, s/d. (12 lâminas). 
No teto da segunda sala, sua protagonista, a Sabedoria, traz uma joeira na mão simbolizando o cuidado na pesquisa, acompanhada por uma sanca que mantém quatro figuras femininas, agora: Honra, Virtude, Fortuna e Fama (figura 5).

Figura 6 - Universidade de Coimbra, Biblioteca Joanina (séc. XVIII), Teto da terceira sala

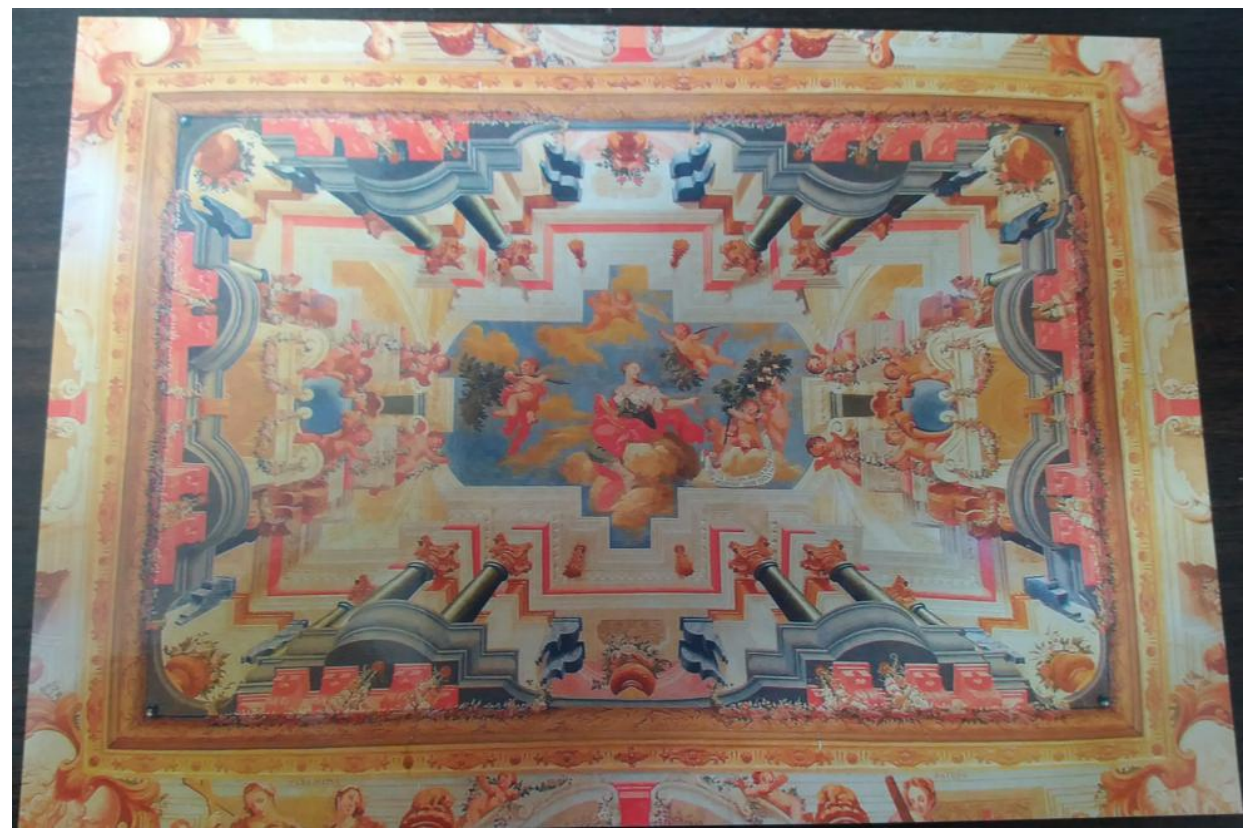

Fonte: Biblioteca Geral da Universidade de Coimbra. Biblioteca Joanina. Coleção de Postais (fotografia, design, execução: SerSilito), Coimbra, BGUC, s/d. (12 lâminas).

Já a terceira sala, tem em seu teto a Sabedoria com uma fita que contém uma citação de Eneida de Virgílio (“É impossível penetrar nos segredos da Terra antes de colher da árvore [da ciência] os ramos com folhagem de ouro"). Na sanca quatro musas a cercam: Teologia e Cânones, Justiça, Ciências Naturais e Artes (figura 6). ${ }^{37}$

Os tetos que apresentam o estilo italiano possuem a pintura de António Simões Ribeiro e o trabalho de douramento feito por Vicente Nunes. Contribuem para a ilusão de ótica barroca de perder-se no infinito e possuir maior altura (efeito trompe-l'oeil). ${ }^{38}$

António Simões Ribeiro estudou na escola de Vicenzo Bacherelli, em Portugal. Tornou-se famoso por ser um pintor de quadraturas, filho de Lisboa, foi responsável pela pintura do teto da antiga Biblioteca do Colégio da Companhia de Jesus, em Salvador, Bahia, no Brasil, na primeira metade do século XVIII. De acordo com Luís de Moura Sobral:

O tecto de Salvador insere-se na longa tradição da decoração das bibliotecas no Ocidente, a qual remonta inevitavelmente à Antiguidade Clássica. Na época barroca, em instituições eclesiásticas católicas, a temática da Sapientia é relativamente frequente. A questão que ela evoca e sintetiza é a dos dois tipos de conhecimento definidos - e opostos um ao outro - séculos e séculos atrás por Santo Agostinho. Por um lado, a Verdade Revelada por Cristo nos Livros Sagrados, acessível através da 
Fé; por outro, a ciência, o conhecimento limitado ao mundo natural, adquirido através da razão humana. Mesmo face ao progresso dos conhecimentos científicos e à gradual laicização da cultura própria dos tempos modernos, a instituição religiosa católica continuou a defender a primazia da Fé e da Revelação. ${ }^{39}$

\section{Um rei, um retrato, uma cenografia de poder: da obra de Domenico Duprà ao walkthough atual}

O nome dado à biblioteca constituiu-se como uma homenagem ao $24^{\circ}$ rei D. João $\mathrm{V}$, patrocinador de sua construção, conhecido como “O Magnânimo”. João Francisco António José Bento Bernardo de Bragança reinou em Portugal de 1706 até sua morte em 1750. Responsável pela construção do Convento de Mafra, inaugurado em 1744, além de teatros em Lisboa, chamava para si o brilho de uma ilustração cultural.

Era no retrato de Corte que a representação individual do soberano aliava o poder à uma cenografia em movimento de renovação da imagem do rei, pautada na matriz de Versalhes, tornando-se documento/monumento de uma personificação cultural, mas sobretudo política. Para Antonio Filipe Pimentel:

O retrato de Corte (entendido como o retrato barroco de aparato) adquire, pois, em tal contexto, protagonismo especial, não somente enquanto objecto estético, mas como objecto político e importante instrumento de domínio. É, assim, neste plano que tem de situar-se a sua invenção no Portugal da primeira metade de setecentos, num tempo e num contexto que assiste à invenção da própria Corte. ${ }^{40}$

Coube ao italiano Giorgio Domenico Duprà criar "um sistema representativo, coerente e homogêneo" em sua pintura de exaltação do patrono real da Corte portuguesa. Assim, por volta de 1725, o retrato de D. João V na Biblioteca da Universidade de Coimbra ocupou seu lugar de centralidade.

Dessa mesma época é também trabalho artístico de Duprà, sob influência francesa de Rigaud e Nattier, "a monumental série ducal, culminando em D. João V e sua prole, no této da Sala dos Tudescos do Palácio de Vila Viçosa". ${ }^{41}$ Em seu estilo de retratista do universo régio sobressai "o valor semântico da cor e mesmo um certo gosto por um intimismo, elegante e velado". 42

Nascido em Turim por volta de 1689, Duprà, estudou pintura em Roma no estúdio de Francesco Trevisani, um especialista em retratos. Chega à Lisboa em 1719, a pedido de D. João V, estando registrado como retratista da Corte até $1730 .^{43}$ 
A importância de Duprà para a Corte de João V foi muito expressiva ao ponto de o pintor relatar que no momento de seu retorno para a Itália, o rei recompensou seus serviços artísticos entregando-lhe onze quilos e meio de ouro. ${ }^{44}$

Figura 7 - Universidade de Coimbra, Biblioteca Joanina (séc. XVIII), Vista geral do interior

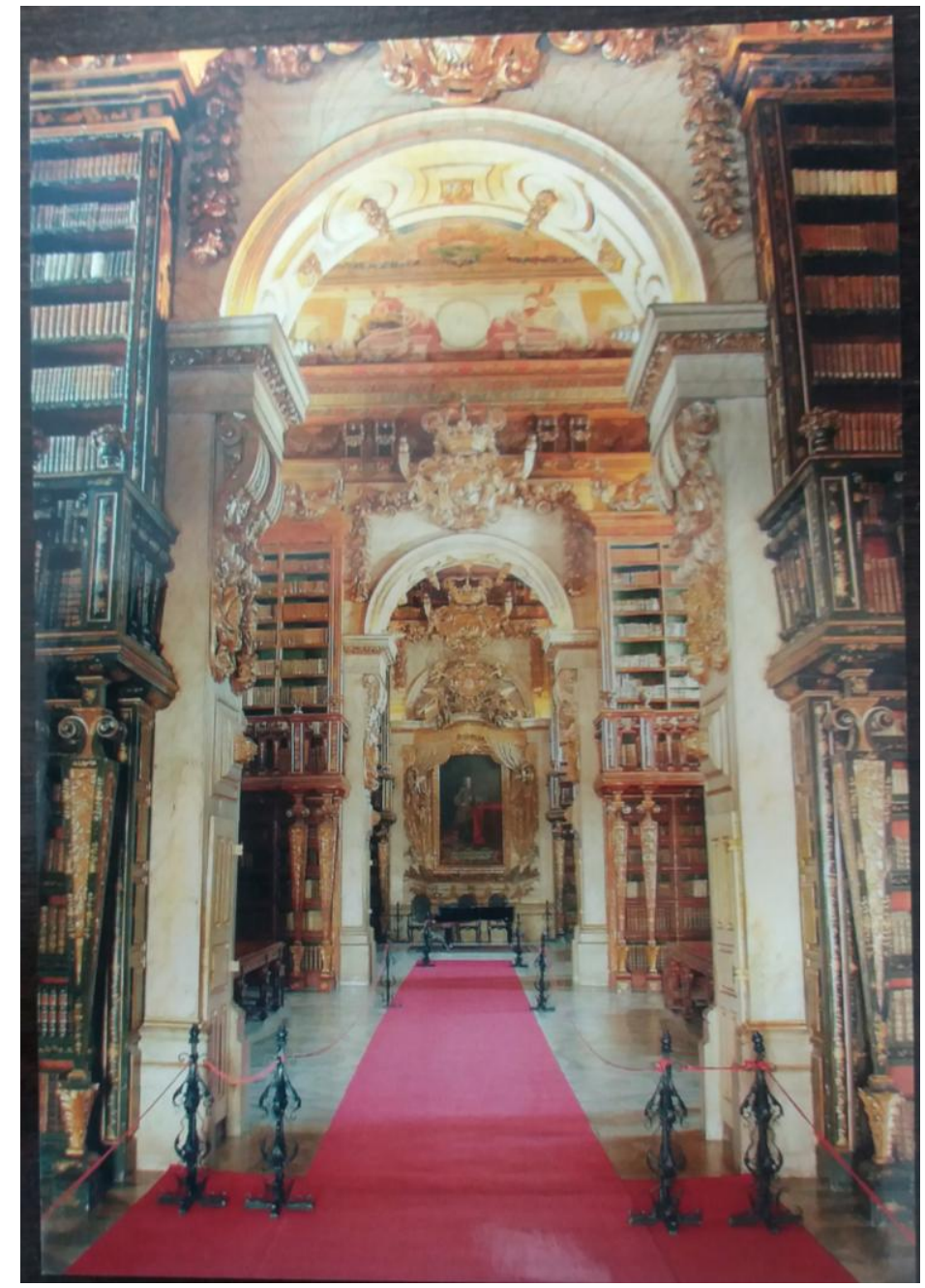

Fonte: Biblioteca Geral da Universidade de Coimbra. Biblioteca Joanina. Coleção de Postais (fotografia, design, execução: SerSilito), Coimbra, BGUC, s/d. (12 lâminas).

Das lâminas que compõem os postais da Biblioteca Joanina da Universidade de Coimbra, perfazendo $10,5 \times 15 \mathrm{~cm}$, dois postais se destacam ao trazerem o retrato pintado por Duprà. Na figura 7, a lâmina apresenta a vista geral do interior do recinto, com a pintura de D. João $\mathrm{V}$ ao fundo, na centralidade do espaço, tendo abaixo um piano de cauda preto. 
Figura 8 - Universidade de Coimbra, Biblioteca Joanina (séc. XVIII), Retrato de D. João V

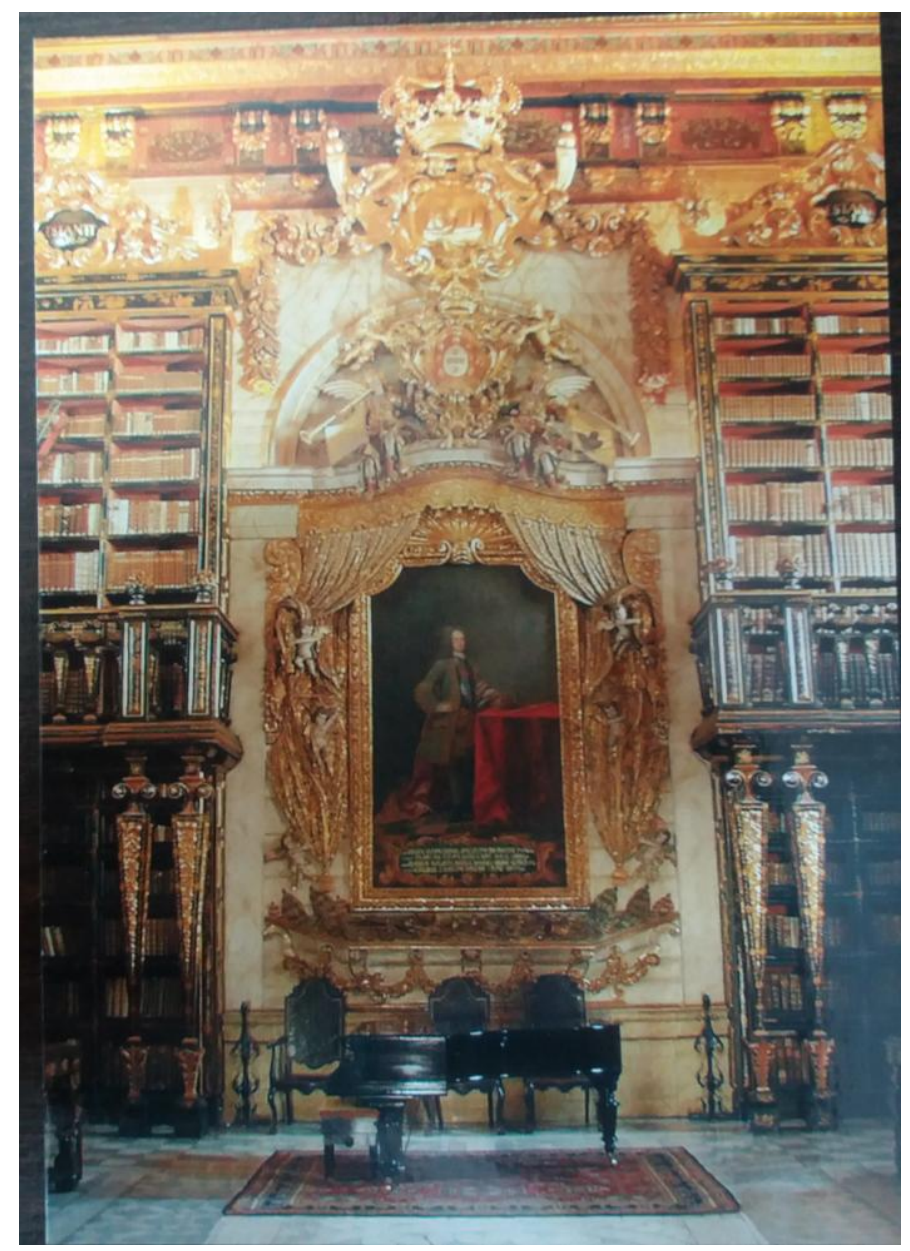

Fonte: Biblioteca Geral da Universidade de Coimbra. Biblioteca Joanina. Coleção de Postais (fotografia, design, execução: SerSilito), Coimbra, BGUC, s/d. (12 lâminas).

O tapete vermelho conduz à representação do monarca cercado por uma moldura dourada, além da imponência do mobiliário que a circunda. Já a figura 8, reproduz um close da sala onde está acondicionado o retrato permitindo identificar os detalhes da obra que traz um rei sério e imponente controlando o poder intelectual que por ele orbita.

$\mathrm{O}$ retrato régio pintado à óleo, representando a efígie de $\mathrm{D}$. João $\mathrm{V}$, está cenograficamente emoldurado, atuando como um "retábulo de um templo-todo-de-ouro" com o monarca em pé sobre um pavimento xadrez, ao lado de uma mesa coberta por um manto rubro, sobre a qual repousa a coroa, onde o monarca repousa a mão esquerda e o cetro real. ${ }^{45}$ Ainda:

D. João V ostenta cabeleira cerimonial, enverga rútilo manto e encontra-se vestido com jaqueta comprida de manga desenvolvida e decorada com brocado de ouro. Por baixo do retratado, ainda na tela, aparece uma cartela pintada com texto panegírico relativo à 'augusta' obra do monarca. ${ }^{46}$ 
A mesma imagem da figura 7 foi escolhida para a capa do DVD-ROM da Biblioteca Joanina, estando também presente na contra-capa onde se pode encontrar um micro-tutorial de abertura das caixas diálogo com acesso ao material informativo contido na mídia (figura 9).

Figura 9 - Contracapa DVD-ROM Biblioteca Joanina

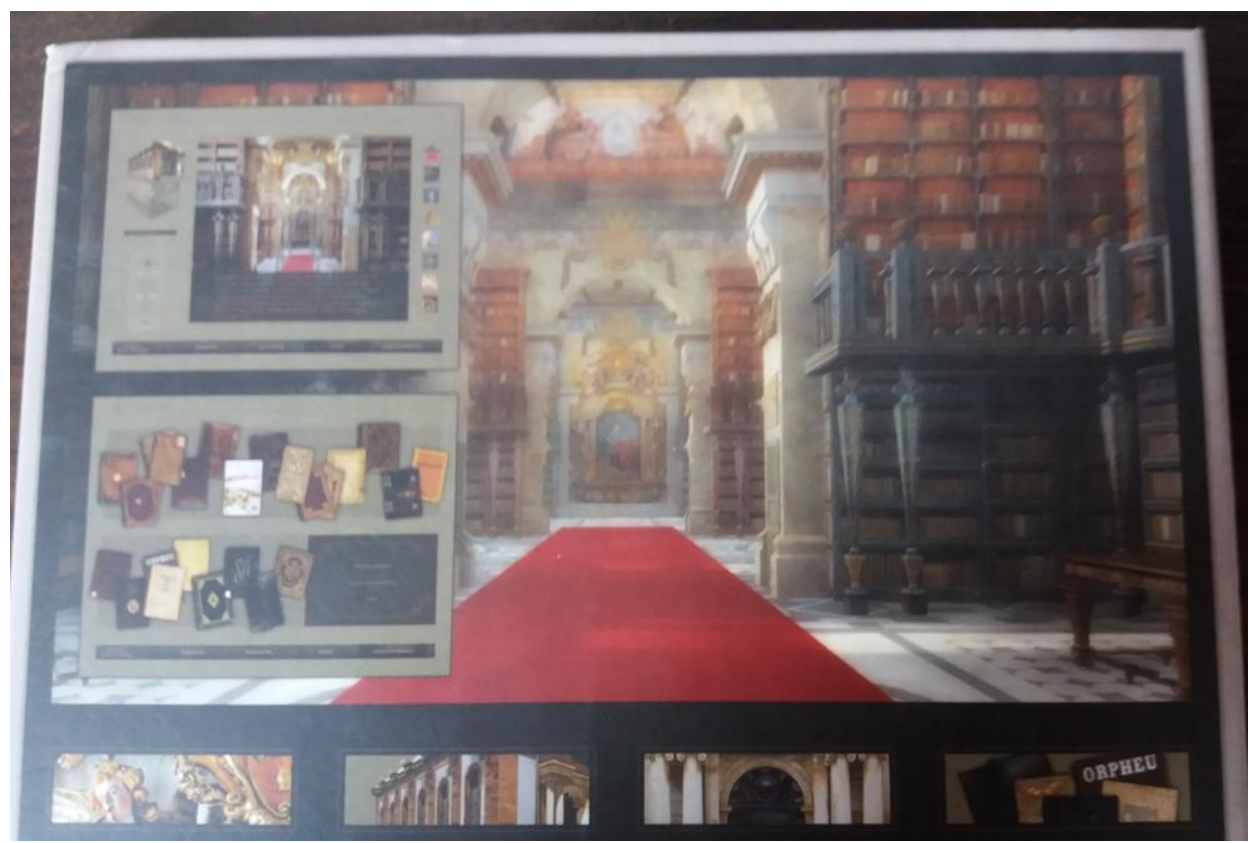

Fonte: Biblioteca Geral da Universidade de Coimbra, Biblioteca Joanina/ João V's Baroque virtual library (DVD-ROM), Coimbra, Universidade de Coimbra, 2008.

A obra é muito semelhante a pintura realizada para ornamentar o Paço de Vila Viçosa, com o rei de corpo inteiro, destacando-se contra um fundo de céu azul, vestindo uma armadura com golas e punhos de renda. Possui ainda o manto de arminho caindo do ombro esquerdo até o chão. Na mão direita segura o bastão de comando, enquanto a mão esquerda pousa sobre uma almofada rubra que acondiciona a coroa. ${ }^{47}$

Além da moldura dourada ao redor da obra pictórica há todo um trabalho artítico esculpido em alto relevo dourado que traz três anjos de cada lado abrindo as cortinas para o rei. Acima, dois arcanjos sopram trombetas anunciando D. João V, tendo ao centro o brasão da realeza.

Por isso o impacto sensorial que a obra régia, enquanto signo de arte e poder, provoca em seus visitantes é descrita detalhadamente por Carlos Fiolhais na condução de seus passos:

Entra-se, passando da clara luz do dia para a espessa penumbra interior, e o primeiro olhar é de um deslumbramento incrédulo. $\mathrm{O}$ dourado parece estar por todo o lado, o brilho procurando vencer o escuro. A vista habitua-se rapidamente à diminuição luminosa e perde-se no interior da Biblioteca, não sabendo bem para onde olhar, tal 
é a profusão da folha dourada, que, nos seus primórdios setecentistas, deveria ofuscar. De facto, entrar na Biblioteca é como entrar numa igreja barroca, com a diferença de que, neste templo secular recheado de livros antigos, o Rei ocupa o lugar do Todo Poderoso. ${ }^{48}$

O DVD-ROM Biblioteca Joanina apresenta a possibilidade de uma visita virtual em 3D, onde a competência técnica permite identifica desde os detalhes arquitetônicos e estéticos do edifício, à sua decoração interna, seu mobiliário com uma riqueza de promenores. A iluminação artificial de luminárias e natural com raios de sol penentrando as vidraças nas janelas compõem parte da ambientação.

No exterior um giro de $360^{\circ}$ permite observar o retângulo formativo, a heráldica portuguesa que figura sobre o portal de acesso contendo as insígnias das faculdades universitárias. Em seu interior três pisos, cada um com tetos conformados por arcos. No piso 1 estão estantes numeradas de madeira abringando uma infinidade de livros e nele é possível, via walkthough (andar através/ passeio virtual) descer ao piso inferior (piso 2) onde estão os cárceres contendo janelas com barras de ferro. No piso 0 encontra-se a Biblioteca Joanina em seu esplendor, reproduzindo 3 salas retangulares interconectadas, com 2 mesas de estudo em cada uma.

O DVD traz ainda 21 obras literárias que foram digitalizadas integralmente e podem ser acessadas em várias pastas contendo mais de 200 arquivos fotográficos.

\section{Considerações Finais}

A relação entre arquitetura, mobiliário e história na Biblioteca Joanina permeia todo o contexto do reinado de D. João V, cujo estilo absolutista "ilustrado" investiu na realização de diversas obras onde a forma, a estética e a suntuosidade elevassem a simbologia do poder régio como mecenas e ao mesmo tempo irradiador do conhecimento.

A biblioteca, ambiência dos livros, por vezes é ofuscada em demasiado pelo brilho do ouro brasileiro, das cores do exotismo oriental, dos ornamentos presentes nos trabalhos realizados por pintores, entalhadores, douradores, mestre de obras, arquitetos estrangeiros e nacionais.

A Biblioteca Joanina de fato imortalizou seu criador, personificou seu "desejo solar", imiscuiu arte, poder e saber de forma bem peculiar, a despeito de toda a crítica ao rei por não ter investido no desenvolvimento da economia portuguesa, e ser fortemente marcado por um arcaísmo de pensamentos e ações. 
O barroco português também sofreu intensas críticas por seu exagero, sua intensidade que chegava a "provocar vertigem" e retirar a funcionalidade de biblioteca do recinto, todavia, persistiu ao longo dos séculos e integra parte importante da história e da própria identidade portuguesa.

Embora a França de Luís XV ditasse moda, a presença de artistas italianos em Portugal setecentista influenciou o estilo e a composição dos artífices portugueses cuja mobilidade para o exercício de seu trabalho cruzou o país e além-mar até a América.

\section{Notas}

1 Carlos Fiolhais; João Carlos Marques, "A BGUC e as Bibliotecas da Universidade de Coimbra", em: https://estudogeral.sib.uc.pt/bitstream/10316/12603/1/A\%20BGUC\%20e\%20as\%20Bibliotecas\%20da\%20Unive rsidade\%20de\%20Coimbra.pdf, acesso 17 de junho de 2017, p.133.

${ }^{2}$ Biblioteca Geral da Universidade de Coimbra. Biblioteca Joanina. Coleção de Postais (fotografia, design, execução: SerSilito), Coimbra, BGUC, s/d. (12 lâminas).

${ }^{3}$ Maria Luísa Cabral, A Real Biblioteca e os seus criadores: em Lisboa, 1755-1803. Lisboa, Biblioteca Nacional de Portugal, 2014.

${ }^{4}$ Biblioteca Geral da Universidade de Coimbra, Coleção de Cartões Postais, op. cit.

${ }^{5}$ Biblioteca Geral da Universidade de Coimbra, Biblioteca Joanina/ João V's Baroque virtual library (DVDROM), Coimbra, Universidade de Coimbra, 2008.

6 Jacques Le Goff, "Documento/Monumento", en Jacques Le Goff. História e Memória, vol.2 - Memória. Lisboa, Edições 70, 2000, p.108.

${ }^{7}$ Maria Helena Correia, "A Música na época de D. João V”, em: http://ancacid.yolasite.com/resources/A\%20M\%C3\%BAsica\%20na\%20\%C3\%A9poca\%20de\%20D.\%20Jo\%C3 $\%$ A3o\%20V.pdf, acesso 17 de junho de 2017, p.2.

8 ParqueExpo, "Coimbra Rio - área de reabilitação urbana. Estudos de caracterização", vol. B, 2012, em: http://www.farmaciadigital.com/coimbravivasru-pt/pdf/coimbra-rio/pp/CoimbraRIO_dossier_B_cap_1.pdf, acesso 19 de junho de 2017, p.4.

${ }^{9}$ Ibidem, p.6.

${ }^{10}$ Governo de Portugal, "Universidade de Coimbra Alta e Sofia Patrimônio Mundial", Apresentação para UNESCO, em: http://www.uc.pt/ruas/property/apres_pt_bem.pdf, acesso 19 de junho de 2017, p.19-20.

${ }^{11}$ Ibidem, p.21.

12 Dulcyene Maria Ribeiro, A formação dos engenheiros militares: Azevedo Fortes, Matemática e ensino de Engenharia Militar no século XVIII em Portugal e no Brasil, Tese de Doutorado, São Paulo, Universidade de São Paulo/Programa de Pós-Graduação da Faculdade de Educação, 2009, p.16.

${ }^{13}$ Ibidem, p. 16.

${ }^{14}$ Ibidem, p. 16.

15 A. E. Maia do Amaral (Coord.), Tesouros da Biblioteca Geral da Universidade de Coimbra, Coimbra, Imprensa da Universidade de Coimbra, 2009, p.17.

16 A. E. Maia do Amaral, "Biblioteca Joanina da Universidade de Coimbra", Discover Baroque Art, Museum With No Frontiers, 2017, em: http://www.discoverbaroqueart.org/database_item.php?id=monument;BAR;pt;Mon11;11;pt, acesso em: 18 de junho de 2017, p. 1.

${ }_{17}^{17}$ A. E. Maia do Amaral (Coord.), Tesouros da Biblioteca Geral da Universidade de Coimbra, op.cit., p.17.

${ }^{18}$ Bernardo de Brito Botelho apud Florencio Mago Barreto-Feio. Memoria historica e descriptiva, á cêrca da Bibliotheca da Universidade de Coimbra e mais estabelecimentos annexos contendo vários esclarecimentos officiaes e reflexões bibliographicas. Coimbra: Imprensa da Universidade, 1857, p.7.

${ }^{19}$ Florencio Mago Barreto-Feio. Memoria historica e descriptiva...op. cit., p.9.

${ }^{20}$ Tania Maria Tavares Bessone, Palácios de Destinos Cruzados: Bibliotecas, Homens e Livros no Rio de Janeiro (1870-1920), São Paulo, EDUSP, 2015. 
${ }^{21}$ Katherine Both, Bibliotecas Universitárias: Análise da Organização, Flexibilidade e Adaptabilidade dos seus Espaços, Dissertação de Mestrado em Arquitetura, Lisboa: Instituto Superior Técnico/Universidade de Lisboa, 2012, p.33.

${ }^{22}$ José Hermano Saraiva, História concisa de Portugal, Lisboa, Publicações Europa-América, 2007, p.242-243.

23 Arabella Galvão, História do Mobiliário, Curitiba, Universidade Federal do Paraná, 2016, em: http://www.exatas.ufpr.br/portal/degraf arabella/wp-content/uploads/sites/28/2016/08/ApostilaHist\%C3\%B3ria-do-Mobili\%C3\%A1rio.pdf, acesso em 18 de junho de 2017, p.8.

${ }^{24}$ A. E. Maia do Amaral, "Biblioteca Joanina da Universidade de Coimbra", op. cit., p.3.

${ }^{25}$ Ibidem, p.3.

${ }^{26}$ Ibidem, p.3.

27 José Pedro Paiva, José Augusto Cardoso Bernardes e Paulo Gama Mota (Coord.), Do sul ao sol: a Universidade de Coimbra e a China, Coimbra, Imprensa da Universidade de Coimbra, 2013, p.107.

${ }^{28}$ Ibidem, p. 108.

${ }^{29}$ Carlos Fiolhais, Biblioteca Joanina, Coimbra, Imprensa da Universidade de Coimbra, 2014, p.27 e A. E. Maia do Amaral (Coord.), Tesouros da Biblioteca Geral da Universidade de Coimbra, op. cit., p.17.

${ }^{30}$ A. E. Maia do Amaral, "Biblioteca Joanina da Universidade de Coimbra”, op. cit. e Biblioteca Geral da Universidade de Coimbra. Biblioteca Joanina. op.cit.

${ }^{31}$ A. E. Maia do Amaral, Tesouros da Biblioteca Geral da Universidade de Coimbra, op. cit, p.17.

${ }^{32}$ Carlos Fiolhais, Biblioteca Joanina, op. cit., p. 27.

${ }^{33}$ António José de Oliveira, "A actividade de entalhadores, douradores e pintores do Entre-Douro-e-Minho em Guimarães (1572-1798)", Actas VII Colóquio Luso-Brasileiro de História da Arte - Artistas e artífices e a sua mobilidade no mundo de expressão portuguesa, Porto, Departamento de Ciências e Técnicas do Patrimônio/ Faculdade de Letras da Universidade do Porto, 2007, p.77.

${ }^{34}$ A. E. Maia do Amaral, Tesouros da Biblioteca Geral da Universidade de Coimbra, op. cit., p.17.

35 Ibidem, p. 27.

${ }^{36}$ Terezinha Elizabeth da Silva, "Bibliotecas: metáforas da memória", Enc. Bibli. R. Eletr. Bibliotecon. Ci. Inf., Florianópolis, n. 21, $1^{\text {o }}$ sem, 2006, p. 89.

${ }^{37}$ A. E. Maia do Amaral, Tesouros da Biblioteca Geral da Universidade de Coimbra, op. cit., p.29.

${ }^{38}$ Ibidem, p. 168.

${ }^{39}$ Luís de Moura Sobral, "Uma nota sobre ilusionismos e alegorias na pintura barroca de Salvador da Bahia", Varia Historia, Belo Horizonte, vol. 24, $\mathrm{n}^{\mathrm{o}}$ 40: p.511-522, jul/dez 2008, em: http://www.scielo.br/scielo.php?script=sci_arttext\&pid=S0104-87752008000200011\&lng=en\&nrm=iso, acesso 18 de Junho de 2017, p.515.

${ }^{40}$ Antonio Filipe Pimentel, "Os pintores de D. João V e a invenção de retrato de Corte", Revista de História da Arte, n $^{\circ}$ 5, pp. 132-151, 2008, em: https://run.unl.pt/bitstream/10362/12605/1/ART_7_Pimentel.pdf, acesso 17 de junho de 2017, p.133.

${ }^{41}$ Ibidem, p. 143.

42 Ibidem, p. 144.

43 Alberto Cottino, "Domenico Duprà (verbete)", Dizionario Biografico degli Italiani, vol. 42, 1993, em: http://www.treccani.it/enciclopedia/domenico-dupra_(Dizionario-Biografico)/, acesso 17 de junho de 2017.

${ }_{44}$ A. de Carvalho, "D. D. royal portrait painter to various European courts", Connoisseur Year Book, 1958, pp. 78-85.

${ }^{45}$ José Francisco de Faria Costa e Maria Helena da Cruz Coelho (Cord.), A Universidade de Coimbra. O tangível e o intangível. Coimbra, Imprensa da Universidade de Coimbra, 2009, p.309.

${ }^{46}$ Ibidem, p. 309.

${ }^{47}$ Ana Alexandra Pereira Pires, A representação da figura na pintura a óleo das rainhas de Portugal D. Maria Ana de Áustria, D. Mariana Vitória e D. Maria I, Dissertação de Mestrado em História da Arte Portuguesa, Porto, Departamento de Ciências e Técnicas do Património/Faculdade de Letras da Universidade do Porto, 2011, p. 31.

${ }^{48}$ Carlos Fiolhais, Biblioteca Joanina, op. cit., p.15.

\section{Referências Bibliográficas}

AMARAL, A. E. Maia do. Biblioteca Joanina da Universidade de Coimbra. In: Discover Baroque Art, Museum With No Frontiers, 2017. Disponível em: 
$<$ http://www.discoverbaroqueart.org/

database_item.php?id=monument;BAR;pt;Mon11;11;pt>. Acesso em: 18 jun. de 2017.

A. E. Maia do (Coord.). Tesouros da Biblioteca Geral da Universidade de Coimbra. Coimbra: Imprensa da Universidade de Coimbra, 2009.

BARRETO-FEIO, Florencio Mago. Memoria historica e descriptiva, á cêrca da Bibliotheca da Universidade de Coimbra e mais estabelecimentos annexos contendo vários esclarecimentos officiaes e reflexões bibliographicas. Coimbra: Imprensa da Universidade, 1857.

BESSONE, Tania Maria Tavares. Palácios de Destinos Cruzados: Bibliotecas, Homens e Livros no Rio de Janeiro (1870-1920). São Paulo: EDUSP, 2015.

BIBLIOTECA GERAL DA UNIVERSIDADE DE COIMBRA. Biblioteca Joanina. Coleção de Postais (fotografia, design, execução: SerSilito). Coimbra: BGUC, s/d. (12 lâminas).

. Biblioteca Joaninal João V's Baroque virtual library (DVD-ROM). Coimbra: Universidade de Coimbra, 2008.

BOTH, Katherine. Bibliotecas Universitárias: Análise da Organização, Flexibilidade e Adaptabilidade dos seus Espaços. Dissertação de Mestrado em Arquitetura. Lisboa: Instituto Superior Técnico/Universidade de Lisboa, 2012.

CABRAL, Maria Luísa. A Real Biblioteca e os seus criadores: em Lisboa, 1755-1803. Lisboa: Biblioteca Nacional de Portugal, 2014.

CARVALHO, A. de. D. D. royal portrait painter to various European courts In: Connoisseur Year Book, 1958.

CORREIA, Maria Helena. A Música na época de D. João V. Disponível em: $<$ http://ancacid.yolasite.com/resources/A\%20M\%C3\%BAsica\%20na\%20\%C3\%A9poca\%20d e\%20D.\%20Jo\%C3\%A3o\%20V.pdf>. Acesso em: 17 jun. 2017.

COSTA, José Francisco de Faria; COELHO, Maria Helena da Cruz (Coord.). A Universidade de Coimbra. O tangível e o intangível. Coimbra: Imprensa da Universidade de Coimbra, 2009.

COTTINO, Alberto. Domenico Duprà (verbete) In: Dizionario Biografico degli Italiani, vol. 42, 1993. Disponível em: <http://www.treccani.it/enciclopedia/domenico-dupra_(DizionarioBiografico)>. Acesso 17 jun. de 2017.

FIOLHAIS, Carlos; MARQUES, João Carlos. A BGUC e as Bibliotecas da Universidade de Coimbra. Disponível em: <https://estudogeral.sib.uc.pt/bitstream/10316/12603/1/A\%20BGUC\%20e\%20as\%20Bibliote cas\%20da\%20Universidade\%20de\%20Coimbra.pdf>. Acesso em: 17 jun. 2017.

GALVÃO, Arabella. História do Mobiliário. Curitiba: Universidade Federal do Paraná, 2016. Disponível em: <http://www.exatas.ufpr.br/portal/degraf_arabella/wpcontent/uploads/sites/28/2016/08/Apostila-Hist\%C3\%B3ria-do-Mobili\%C3\%A1rio.pdf>.

Acesso em: 18 jun. de 2017.

GOVERNO DE PORTUGAL. Universidade de Coimbra Alta e Sofia Patrimônio Mundial, Apresentação para UNESCO. Disponível em: $<$ http://www.uc.pt/ruas/property/apres_pt_bem.pdf $>$. Acesso em: 19 jun. 2017.

LE GOFF, Jacques. Documento/Monumento. In:__. História e Memória, vol.2 - Memória. Lisboa: Edições 70, 2000.

OLIVEIRA, António José de. A actividade de entalhadores, douradores e pintores do EntreDouro-e-Minho em Guimarães (1572-1798) In: Actas VII Colóquio Luso-Brasileiro de História da Arte - Artistas e artífices e a sua mobilidade no mundo de expressão portuguesa. Porto: Departamento de Ciências e Técnicas do Patrimônio/ Faculdade de Letras da Universidade do Porto, 2007. 
PAIVA, José Pedro; BERNARDES, José Augusto Cardoso; MOTA, Paulo Gama (Coord.). Do sul ao sol: a Universidade de Coimbra e a China. Coimbra: Imprensa da Universidade de Coimbra, 2013.

PARQUEEXPO. Coimbra Rio - área de reabilitação urbana. Estudos de caracterização, vol. B, 2012, Disponível em: <http://www.farmaciadigital.com/coimbravivasru-pt/pdf/coimbrario/pp/CoimbraRIO_dossier_B_cap_1.pdf $>$. Acesso em: 19 jun. 2017.

PIMENTEL, Antonio Filipe. Os pintores de D. João V e a invenção de retrato de Corte In: Revista de História da Arte, $\mathrm{n}^{\circ} 5$, pp. 132-151, 2008. Disponível em: <https://run.unl.pt/bitstream/10362/12605/1/ART_7_Pimentel.pdf>. Acesso 17 jun. 2017.

PIRES, Ana Alexandra Pereira. A representação da figura na pintura a óleo das rainhas de Portugal D. Maria Ana de Áustria, D. Mariana Vitória e D. Maria I. Dissertação de Mestrado em História da Arte Portuguesa. Porto: Departamento de Ciências e Técnicas do Património/Faculdade de Letras da Universidade do Porto, 2011.

RIBEIRO, Dulcyene Maria. A formação dos engenheiros militares: Azevedo Fortes, Matemática e ensino de Engenharia Militar no século XVIII em Portugal e no Brasil. Tese de Doutorado. São Paulo: Universidade de São Paulo/Programa de Pós-Graduação da Faculdade de Educação, 2009.

SARAIVA, José Hermano. História concisa de Portugal. Lisboa: Publicações EuropaAmérica, 2007.

SILVA, Terezinha Elizabeth da. Bibliotecas: metáforas da memória. In: Enc. Bibli. R. Eletr. Bibliotecon. Ci. Inf., Florianópolis, n. 21, 1ºm, 2006.

SOBRAL, Luís de Moura. Uma nota sobre ilusionismos e alegorias na pintura barroca de Salvador da Bahia In: Varia História, Belo Horizonte, vol. 24, n 40: p.511-522, jul/dez 2008. Disponível em: $\quad$ http://www.scielo.br/scielo.php?script=sci_arttext\&pid=S0104-

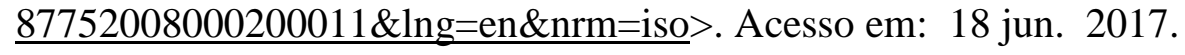

